\title{
STUDI TENTANG KECERDASAN BUDAYA MAHASISWA CALON GURU PENDIDIKAN EKONOMI FKIP UNIVERSITAS SAMAWA SUMBAWA BESAR
}

\author{
OLEH:
}

SUHARLI

suharliyazupal@yahoo.com

\section{(Dosen Program Studi Pendidikan Ekonomi FKIP Universitas Samawa Sumbawa Besar)}

\begin{abstract}
ABSTRAK
Era globalisasi membuka peluang terbentuknya pasar kerja internasional. Dengan demikian interaksi lintas wilayah sulit untuk dihindari. Interaksi lintas budaya dalam masyarakat multi budaya dengan situasi masyarakat global merupakan tantangan yang harus diwaspadai sebagai salah satu sumber konflik. Upaya untuk meningkatkan kemampuan individu dalam masyarakat global sehingga terbangun interaksi lintas budaya yang harmonis, maka kecerdasan budaya merupakan salah satu kemampuan yang harus dikembangkan. Mengingat begitu pentingnya kecerdasan budaya, maka mahasiswa sebagai calon pendidik juga perlu dibekali kecerdasan budaya sebagai modal untuk membimbing dan mengajar para siswanya agar memiliki kemampuan dalam memahami, menyelami dan berperilaku adaptif terhadap budaya orang lain. Untuk bisa meningkatkan kecerdasan budaya mahasiswa calon guru khususnya mahasiswa pendidikan Ekonomi di FKIP Universitas Samawa Sumbawa Besar, maka terlebih dahulu perlu dikaji sejauhmana kecerdasan budaya tersebut sudah melekat pada diri mahasiswa. Mengukur tingkat kecerdasan budaya mahasiswa calon guru dapat dilakukan dengan mengumpulkan informasi menggunakan questioner sebagai instrument yang dikembangkan sesuai dengan teori kecerdasan budaya yang telah dikembangkan oleh beberapa ahli seperti David Livermore dan lain-lain. Berdasarkan data yang diperoleh dapat dijelaskan bahwa pada komponen metakognitif CQ diperoleh skor rata-rata angket sebesar 66.18\%. Pada kategori kognitif CQ diperoleh data angket sebesar 57.07\%. Selanjutnya pada faktor motivasi CQ berdasarkan hasil analisis data angket diperoleh rata-rata skor angket sebesar $67.23 \%$. Sedangkan pada faktor perilaku dari kecerdasan budaya, diperoleh skor ratarata data angket sebesar $59.08 \%$. dengan demikian maka perolehan data tersebut juga masih termasuk ke dalam kategori baik. Berdasarkan hasil analisis secara keseluruhan dari keempat faktor kecerdasan budaya tersebut di atas diperoleh rata-rata skor angket sebesar $62.39 \%$. Dengan demikian maka secara keseluruhan dapat dikatakan bahwa tingkat kecerdasan budaya mahasiswa pendidikan ekonomi di FKIP Universitas Samawa Sumbawa Besar termasuk ke dalam kategori baik.
\end{abstract}

Kata kunci: Kecerdasan Budaya, Mahasiswa Calon Guru, Pendidikan Ekonomi. 


\section{Latar Belakang}

Berlakunya konsep globalisasi saat ini telah membawa konsekuensi yang sangat luas dalam setiap aspek kehidupan manusia tanpa terkecuali, termasuk dalam dunia pendidikan dengan seluruh komponen yang ada di dalamnya. Globalisasi yang terjadi telah meningkatkan interaksi antar budaya, sehingga meningkatkan kemungkinan terjadinya kesalahpahaman, ketegangan dan konflik budaya (Ang, Dyne, \& Tan, 2010).

Semakin terintegrasinya dunia pendidikan saat ini dengan berbagai budaya bangsa dan budaya luar, seakan menghilangkan batas antar Negara. Dengan demikian maka para generasi bangsa sudah seharusnya dipersiapkan dengan beragam kompetensi agar mampu berinteraksi dan beradaptasi dengan budaya yang berbeda dan salah satu kompetensi tersebut adalah kecerdasan budaya. Kecerdasan budaya sebagai kemampuan individu dalam memahami, berpikir dan berperilaku secara efektif dalam situasi-situasi yang bercirikan perbedaan antar budaya sangat diperlukan agar mampu beradaptasi dengan baik dalam situasi budaya global sehingga menjadi insan yang cerdas budaya.

Sejalan dengan pendapat tersebut di atas, dalam rangka mewujudkan cita-cita mencerdaskan kehidupan bangsa, visi pendidikan dan kebudayaan tahun 2025 adalah menghasilkan insan Indonesia yang cerdas dan kompetitif (insan kamil/paripurna) yaitu insan yang cerdas secara spiritual, cerdas secara emosional, cerdas secara sosial, cerdas intelektual dan cerdas secara kinestetik (Kemendiknas, 2010:30).

Membangun insan yang cerdas dan kompetitif yang di dalamnya tersirat kecerdasan budaya merupakan suatu keharusan dalam masyarakat Indonesia yang multikultural. Indonesia merupakan negara yang terdiri dari berbagai kelompok etnis, budaya, suku, dan agama sehingga secara sederhana dapat disebut sebagai masyarakat multikultural. Akan tetapi, realitas multikultural tersebut berhadapan dengan kebutuhan rekonstruksi kebudayaan nasional yang dapat menjadi integrating force yang mengikat seluruh keragaman etnis dan budaya tersebut. Kemajemukan tersebut juga menyimpan potensi konflik yang dapat mengancam kehidupan berbangsa dan bernegara. Keragaman masyarakat Indonesia bukan saja terjadi pada tingkat nasional, akan tetapi juga terjadi pada tingkat lokal sehingga peluang terjadinya konflik sangat terbuka.

Sebagai cntoh, kabupaten Sumbawa yang merupakan salah satu dari sembilan kabupaten/kota yang ada di Nusa Tenggara Barat, juga berada pada kondisi masyarakat yang sangat beragam. Secara geografis kabupaten Sumbawa terletak pada posisi yang cukup strategis, yaitu berada pada segi tiga emas kawasan pariwisata antara pulau Bali, Lombok dan pulau Komodo. Jumlah penduduk seluruhnya 452.746 jiwa, (laki-laki 228.717 jiwa dan 
perempuan 224.029 jiwa). Sedangkan jumlah penduduk asli (etnis Samawa) mencapai 68,66\% selebihnya adalah berasal dari etnis Bali, Sasak (Lombok), Jawa, Sunda, Madura, Mbojo (Bima/Dompu), Bugis Makasar, Minang, Sumba/Timor, dan Arab (Syaifuddin Iskandar, 2010: 1). Banyaknya masyarakat pendatang yang menetap dan menjadi bagian dari masyarakat Sumbawa membuka ruang bagi terjadinya interaksi lintas budaya. Perbedaan budaya masyarakat pendatang dengan masyarakat stempat menjadi unsur kemajemukan yang berpeluang menjadi potensi konflik di masyakat sehingga sedini mungkin diperlukan tindakan antisipatif.

Universitas Samawa Sumbawa Besar sebagai salah satu lembaga Pendidikan Tinggi merupakan wadah bagi pengembangan kompetensi kecerdasan budaya bagi para mahasiswa termasuk mahasiswa calon guru. Keberagaman latar belakang budaya dan rendahnya pemahaman budaya yang dimiliki dapat menjadi salah satu pemicu konflik yang terjadi selama ini. Oleh karena itu, sebagai upaya untuk mengembangkan kecerdasan budaya yang dimiliki oleh mahasiswa maka terlebih dahulu perlu dikaji sejauhmana tingkat kecerdasan budaya yang telah dimiliki selama ini.

Dengan demikian, penelitian ini akan difokuskan pada studi kecerdasan budaya mahasiswa calon guru, khususnya di Program Studi Pendidikan Ekonomi Fakultas Keguruan dan Ilmu Pendidikan Universitas Samawa Sumbawa Besar yaitu sejauhmana tingkat kecerdasan budaya yang dimiliki oleh mahasiswa sebagai kemampuan dalam memahami, kemampuan adaptasi selama berinteraksi dalam situasi dan kondisi budaya yang berbeda.

\section{Kajian Teori}

Kemampuan untuk berinteraksi secara efektif dalam berbagai budaya, baru-baru ini diberi label sebagai kecerdasan budaya (CQ) yang merupakan salah satu kontribusi terbaru tentang kecerdasan, dan mendapatkan tempat bersama kecerdasan emosional, interpersonal dan sosial. (Yvonne du Plessis, 2011: 3). Upaya memahami dan menyelami situasi multikultural dengan kemampuan adaptasi yang baik, maka peningkatan kecerdasan budaya pada masyarakat sangat diperlukan. Joo-Seng Tan, (2004: 1) mengatakan bahwa di antara keterampilan di abad ke dua puluh satu yang sering berbicara adalah tentang kemampuan untuk beradaptasi secara terus-menerus dengan orang yang berbeda budaya dan kemampuan untuk mengelola keterkaitan dunia saat ini. Joo-Seng Tan (2004) dan Kok-Yee Ng dan P. Christopher Earley (2006) menjelaskan bahwa Cultural intelligence berimplikasi pada lingkungan kerja global yang beragam dimana tenaga kerja yang adaptable sangat dibutuhkan. Jadi, Cultural Intelligence memiliki aplikasi penting bagi individu, tim, dan organisasi untuk berfungsi dalam lingkungan yang multikultural. 
Livermore (2011) mendefinisikan kecerdasan budaya sebagai kemampuan untuk berfungsi secara efektif dalam berbagai konteks budaya yang bervariasi. Kecerdasan Budaya merujuk pada kemampuan individu dalam memahami, berpikir dan berperilaku secara efektif dalam situasi-situasi yang bercirikan perbedaan antar budaya (Ang., et.all., 2008). Menurut Ang, dkk. (2014), kecerdasan budaya ini mirip dengan kecerdasan sosial dan kecerdasan emosional. Kecerdasan sosial merujuk pada kemampuan untuk memahami dan mengelola hubungan sosial dengan orang lain. Kecerdasan emosional merupakan kemampuan dalam memahami dan menghadapi (mengelola) emosi diri sendiri dan emosi orang lain. Sedangkan kecerdasan budaya adalah kemampuan untuk memahami, mengelola, dan berhadapan dengan emosi-emosi orang lain dalam konteks antar budaya. Dengan demikian, kecerdasan budaya merupakan salah satu bentuk spesifik dari kecerdasan interpersonal.

Komponen kecerdasan budaya (CQ) menurut Earley and Ang (Ebrahim Khodadady dan Shima Ghahari, 2011:5) terdiri dari komponen meta-kognitif, kognitif, motivasi dan perilaku. Sebagai komponen pertama, CQ meta-kognitif mencerminkan proses digunakan individu untuk memperoleh dan memahami pengetahuan budaya. CQ kognitif, sebagai komponen kedua, mengacu pada pengetahuan seseorang dan pemahaman tentang bagaimana budaya mirip dengan dan berbeda satu sama lain. Hal ini mencerminkan struktur pengetahuan umum dan peta mental tentang budaya dan mencakup pengetahuan tentang sistem ekonomi dan hukum, norma-norma sosial, keyakinan agama, praktik dan konvensi dalam budaya yang berbeda yang diperoleh dari pendidikan dan pengalaman pribadi. Sebagai komponen ketiga, CQ motivasi menunjukkan kemampuan seseorang tentang motivasi dalam belajar dan berfungsi dalam situasi lintas budaya. Ini termasuk sesuatu yang melekat pada seseorang dalam mengalami dan berinteraksi dengan orang-orang dari budaya yang berbeda. Komponen terakhir, CQ perilaku, mengacu pada kemampuan seseorang untuk menunjukkan perilaku verbal dan nonverbal yang tepat ketika berinteraksi dengan orang-orang dari budaya yang berbeda.

Alat ukur kecerdasan budaya yang digunakan adalah berbentuk kuesioner kecerdasan budaya dengan merujuk pada alat ukur kecerdasan budaya pada Cultural Intelligence Center tahun 2005. 
Tabel 1. Dimensi dan Indikator Kecerdasan Budaya

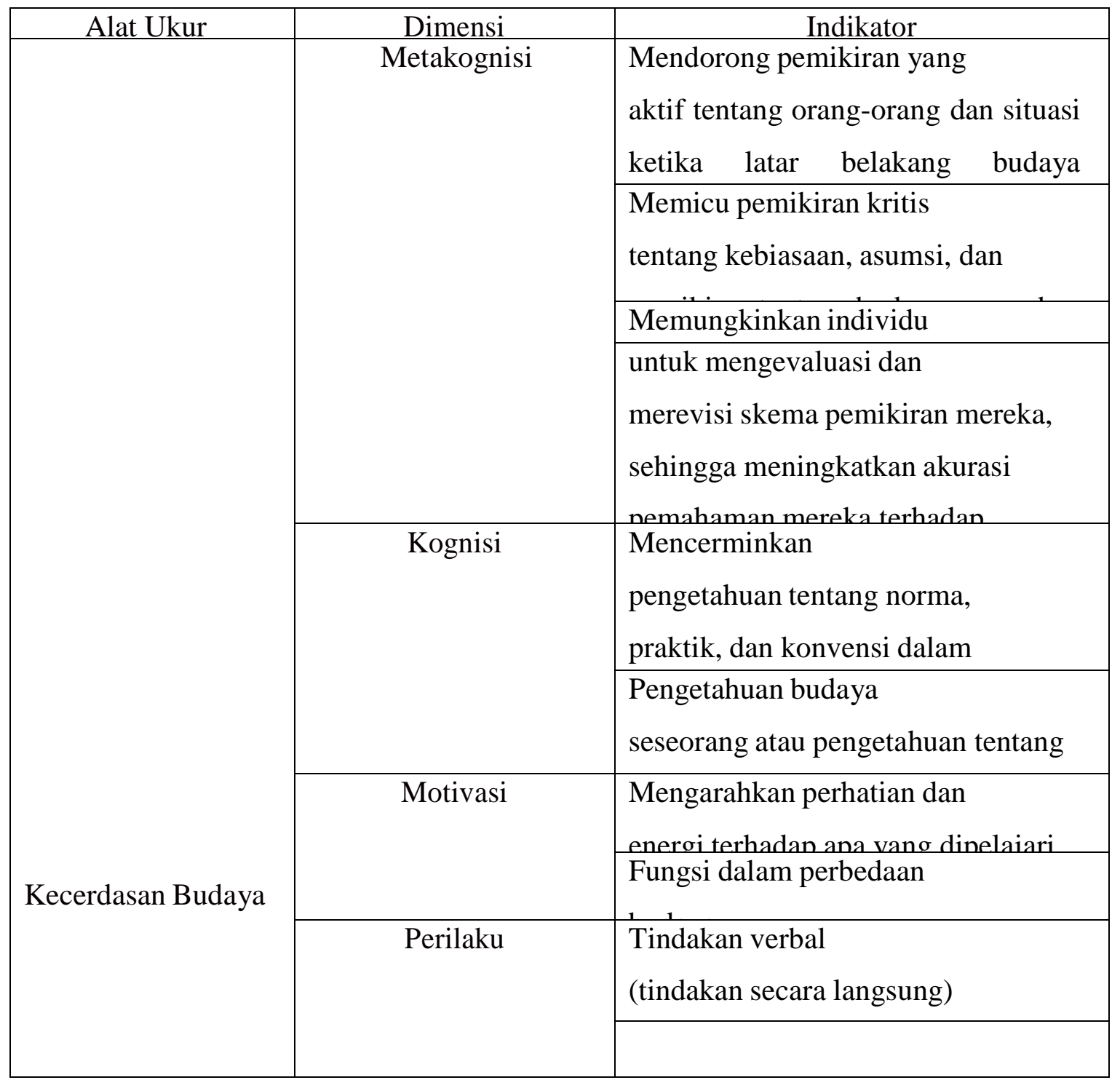

\section{Metode Penelitian}

Jenis penelitian yang digunakan adalah penelitian kuantitatif, yaitu suatu proses menemukan pengetahuan yang menggunakan data berupa angka sebagai alat untuk menemukan keterangan mengenai apa yang ingin kita ketahui, S. Margono (2010: 105). Sedangkan metode penelitian yang digunakan adalah metode survei. Masri Singarimbun \& Sofian Effendi (2006: 3) mendefinisikan penelitian survei adalah penelitian yang mengambil sampel dari satu populasi dan menggunakan kuesioner sebagai pengumpulan data yang pokok. Sedangkan Sukardi (2009: 193), menjelaskan penelitian survei merupakan kegiatan penelitian yang mengumpulkan data tertentu dengan tiga tujuan penting, diantaranya: (1). Mendeskripsikan keadaan yang alami yang hidup pada saat itu; (2). Mengidentifikasi secara terukur keadaan sekarang untuk dibandingkan; (3). Menentukan hubungan sesuatu yang 
hidup diantara kejadian spesifik. Dengan demikian metode survey yang dimaksudkan dalam penelitian ini adalah metode penelitian yang menggunakan kuesioner untuk mengumpulkan data guna mendeskripsikan keadaan terkait dengan kecerdasan budaya mahasiswa calon guru.

Populasi dalam penelitian ini adalah mahasiswa pendidikan ekonomi FKIP Universitas Samawa. Sedangkan yang menjadi sampel dalam penelitian ini adalah dipilih secara acak sebanyak 34 orang mahasiswa terutama yang sudah berada antara semester empat sampai semester enam dengan pertimbangan bahwa mereka telah banyak melakukan interaksi dengan sesama mahasiswa lain terutama yang berlatar belakang budaya berbeda.

Teknik pengumpulan data yang digunakan adalah kuesioner. Kuesioner merupakan teknik pengumpulan data yang dilakukan dengan cara memberikan seperangkat pertanyaan kepada responden untuk dijawab. Jenis kuesioner yang digunakan dalam penelitian ini adalah kuesioner semantik diferensial. Semantic differential adalah salah satu bentuk instrumen pengukuran yang berbentuk skala, yang digunakan untuk mengukur reaksi terhadap stimulus, kata-kata, dan konsep-konsep dan dapat disesuaikan untuk orang dewasa atau anak-anak dari budaya manapun juga. Semantic differential digunakan untuk dua tujuan: (1) untuk mengukur secara objektif sifat-sifat semantik dari kata atau konsep dalam ruang semantik tiga dimensional dan (2) sebagai skala sikap yang memusatkan perhatian pada aspek afektif atau dimensi evaluatif (Issac dan Michael, 1984: 144-145 dan Heise, 2006: 1 dalam Bambang Prihadi, 2013:4). Dalam penelitian ini, skala semantik lebih difokuskan pada tujuan yang kedua yaitu untuk mengukur skala sikap mahasiswa pada aspek afektif atau dimensi evaluatif terkait dengan kecerdasan budaya yang dimiliki.

Tahap-tahap pengolahan data hasil penelitian ini adalah sebagai berikut: (1). Pemeriksaan akan kelengkapan jawaban yaitu pada tahap ini data yang diperoleh diperiksa kembali untuk mencari jawaban dari kuesioner yang tidak lengkap; (2). Tally, yaitu menghitung jumlah atau frekuensi dari masing-masing jawaban dalam kuesioner; (3). Menghitung persentase jawaban responden dalam bentuk tabel tunggal melalui distribusi frekuensi dan persentase dengan menggunakan rumus:

$\mathbf{P}=\mathbf{F} / \mathrm{N} \times 100 \%$

P: Persentase

F: Frekuensi data

N: Jumlah sampel yang diolah (Warsito, 1992:59). 
Hasil Penelitian dan Pembahasan

Tabel 2. Hasil Analisis Data Angket

\begin{tabular}{|c|c|c|c|c|c|c|c|c|c|c|c|}
\hline \multicolumn{3}{|c|}{ CQ-Metakognitive } & \multicolumn{3}{|c|}{ CQ-Kognitive } & \multicolumn{3}{|c|}{ CQ-Motivasi } & \multicolumn{3}{|c|}{ CQ-Behaviour } \\
\hline Subjek & skor & $\%$ & subjek & skor & $\%$ & subjek & skor & $\%$ & subjek & skor & $\%$ \\
\hline 1 & 12 & 42.86 & 1 & 18 & 42.86 & 1 & 19 & 54.29 & 1 & 5 & 14.29 \\
\hline 2 & 9 & 32.14 & 2 & 14 & 33.33 & 2 & 20 & 57.14 & 2 & 8 & 22.86 \\
\hline 3 & 18 & 64.29 & 3 & 18 & 42.86 & 3 & 5 & 14.29 & 3 & 8 & 22.86 \\
\hline 4 & 17 & 60.71 & 4 & 21 & 50 & 4 & 18 & 51.43 & 4 & 17 & 48.57 \\
\hline 5 & 28 & 100 & 5 & 29 & 69.05 & 5 & 28 & 80 & 5 & 17 & 48.57 \\
\hline 6 & 28 & 100 & 6 & 28 & 66.67 & 6 & 28 & 80 & 6 & 17 & 48.57 \\
\hline 7 & 21 & 75 & 7 & 35 & 83.33 & 7 & 21 & 60 & 7 & 35 & 100 \\
\hline 8 & 20 & 71.43 & 8 & 42 & 100 & 8 & 21 & 60 & 8 & 22 & 62.86 \\
\hline 9 & 15 & 53.57 & 9 & 32 & 76.19 & 9 & 34 & 97.14 & 9 & 31 & 88.57 \\
\hline 10 & 19 & 67.86 & 10 & 19 & 45.24 & 10 & 32 & 91.43 & 10 & 26 & 74.29 \\
\hline 11 & 18 & 64.29 & 11 & 16 & 38.1 & 11 & 25 & 71.43 & 11 & 25 & 71.43 \\
\hline 12 & 21 & 75 & 12 & 21 & 50 & 12 & 21 & 60 & 12 & 26 & 74.29 \\
\hline 13 & 20 & 71.43 & 13 & 27 & 64.29 & 13 & 20 & 57.14 & 13 & 21 & 60 \\
\hline 14 & 6 & 21.43 & 14 & 26 & 61.9 & 14 & 27 & 77.14 & 14 & 20 & 57.14 \\
\hline 15 & 21 & 75 & 15 & 8 & 19.05 & 15 & 23 & 65.71 & 15 & 6 & 17.14 \\
\hline 16 & 16 & 57.14 & 16 & 19 & 45.24 & 16 & 13 & 37.14 & 16 & 18 & 51.43 \\
\hline 17 & 25 & 89.29 & 17 & 24 & 57.14 & 17 & 30 & 85.71 & 17 & 28 & 80 \\
\hline 18 & 20 & 71.43 & 18 & 23 & 54.76 & 18 & 22 & 62.86 & 18 & 24 & 68.57 \\
\hline 19 & 18 & 64.29 & 19 & 32 & 76.19 & 19 & 20 & 57.14 & 19 & 21 & 60 \\
\hline 20 & 18 & 64.29 & 20 & 32 & 76.19 & 20 & 32 & 91.43 & 20 & 22 & 62.86 \\
\hline 21 & 18 & 64.29 & 21 & 32 & 76.19 & 21 & 32 & 91.43 & 21 & 23 & 65.71 \\
\hline 22 & 18 & 64.29 & 22 & 24 & 57.14 & 22 & 20 & 57.14 & 22 & 17 & 48.57 \\
\hline 23 & 16 & 57.14 & 23 & 24 & 57.14 & 23 & 30 & 85.71 & 23 & 28 & 80 \\
\hline 24 & 22 & 78.57 & 24 & 27 & 64.29 & 24 & 28 & 80 & 24 & 32 & 91.43 \\
\hline 25 & 14 & 50 & 25 & 11 & 26.19 & 25 & 16 & 45.71 & 25 & 15 & 42.86 \\
\hline 26 & 18 & 64.29 & 26 & 20 & 47.62 & 26 & 19 & 54.29 & 26 & 20 & 57.14 \\
\hline 27 & 15 & 53.57 & 27 & 12 & 28.57 & 27 & 19 & 54.29 & 27 & 7 & 20 \\
\hline 28 & 22 & 78.57 & 28 & 32 & 76.19 & 28 & 27 & 77.14 & 28 & 28 & 80 \\
\hline 29 & 15 & 53.57 & 29 & 23 & 54.76 & 29 & 27 & 77.14 & 29 & 24 & 68.57 \\
\hline 30 & 18 & 64.29 & 30 & 12 & 28.57 & 30 & 22 & 62.86 & 30 & 15 & 42.86 \\
\hline 31 & 18 & 64.29 & 31 & 17 & 40.48 & 31 & 26 & 74.29 & 31 & 23 & 65.71 \\
\hline 32 & 22 & 78.57 & 32 & 32 & 76.19 & 32 & 20 & 57.14 & 32 & 20 & 57.14 \\
\hline 33 & 18 & 64.29 & 33 & 29 & 69.05 & 33 & 28 & 80 & 33 & 29 & 82.86 \\
\hline 34 & 26 & 92.86 & 34 & 36 & 85.71 & 34 & 27 & 77.14 & 34 & 25 & 71.43 \\
\hline$\Sigma X$ & $=$ & 2250 & $\Sigma X$ & $=$ & 1940 & $\Sigma X$ & $=$ & 2286 & $\sum X$ & $=$ & 2009 \\
\hline$\sum \bar{X} 1$ & $=$ & 66.18 & $\sum \bar{X} 2$ & $=$ & 57.07 & $\sum \bar{X} 3$ & $=$ & 67.23 & $\sum \bar{X} 4$ & $=$ & 59.08 \\
\hline
\end{tabular}

$\Sigma \bar{X}$ Total $=\frac{\bar{X} 1+\bar{X} 2+\bar{X} 3+\bar{X} 4}{4}=62.39$ 


\section{Pembahasan}

Kecerdasan budaya saat ini menjadi salah satu isu yang menarik untuk di kaji terutama dalam masyarakat multi budaya sehingga diharapkan terbangun komunikasi yang harmonis antar individu dalam masyarakat. Membangun generasi bangsa sebagaimana yang diharapkan terwujud pada tahun 2025 adalah generasi yang cerdas dan kompetitif dengan tidak mengabaikan jati diri sebagai bangsa yang multi budaya. Kecerdasan budaya merupakan kemampuan individu dalam menyelami budaya lain dengan kemampuan memahami atribut akan budaya lain tersebut, kemampuan merasakan dan menyadari bahwa dirinya berada dalam situasi yang berbeda dengan kondisi dirinya, kemampuan menyesuaikan diri dengan budaya lain yang berbeda dan berperilaku dalam interaksi pada situasi lintas budaya. Dengan demikian, pada semua sektor pekerjaan terutama dalam bidang pendidikan, kecerdasan budaya penting untuk dibangun pada setiap calon guru yang akan mendidik generasi calon pemimpin di masa yang akan datang.

Penelitian ini merupakan penelitian yang dilakukan dalam bentuk sederhana untuk menjajaki kondisi kecerdasan budaya mahasiswa. Dikatakan sederhana karena subjek penelitian hanya diambil sebagian kecil dari populasi yaitu sebanyak 34 orang. Berdasarkan hasil analisis data yang telah dilakukan secara sederhana dapat dijelaskan bahwa pada komponen metakognitif CQ diperoleh skor rata-rata angket sebesar 66.18\%. Artinya bahwa mahasiswa memiliki kecenderungan pada kesadaran memahami proses interaksi dengan orang yang berbeda budaya termasuk dalam kategori baik. Pada kategori kognitif CQ diperoleh data angket sebesar 57.07\%. Perolehan skor angket tersebut menunjukkan bahwa mahasiswa memiliki pemahaman akan perbedaan budaya dengan orang lain termasuk dalam kategori baik. Selanjutnya pada faktor motivasi CQ berdasarkan hasil analisis data angket diperoleh nilai rata-rata sebesar $67.23 \%$. Perolehan nilai rata-rata pada faktor kognitif dari kecerdasan budaya termasuk juga ke dalam kategori baik. Sedangkan pada faktor perilaku dari kecerdasan budaya, diperoleh skor rata-rata data angket sebesar 59.08\%. dengan demikian maka perolehan data tersebut juga masih termasuk ke dalam kategori baik. Berdasarkan hasil analisis secara keseluruhan dari keempat faktor kecerdasan budaya tersebut di atas diperoleh rata-rata skor angket sebesar 62.39\%. Dengan demikian maka secara keseluruhan juga perolehan rata-rata skor angket juga termasuk dalam kategori baik. Artinya bahwa tingkat kecerdasan budaya mahasiswa pendidikan ekonomi di FKIP Universitas Samawa Sumbawa Besar termasuk ke dalam kategori baik. 
Berdasarkan hasil analisis tersebut dapat disimpulkan bahwa secara keseluruhan mahasiswa atau sebagian besarnya termasuk telah memiliki kemampuan untuk berinteraksi, menyesuaikan diri, memahami kemampuannya ketika berada di dalam situasi yang berbeda. Kenyataan ini belum dapat peneliti generalisasikan karena sampel dalam penelitian ini terlalu sedikit sehingga untuk mewakili populasi secara keseluruhan perlu peneliti lakukan pengkajian dalam jumlah sampel yang ideal. Walaupun demikian, data hasil penelitian ini cukup menjadi acuan bagi peneliti untuk mengembangkan penelitian selanjutnya secara lebih baik.

Secara lebih detail, kondisi kecerdasan budaya mahasiswa dapat dilihat dari hasil analisis sederhana pada setiap dimensi kecerdasan budaya yang telah disajikan pada table di poin analisis data sebelumnya. Berdasarkan hasil analsis data tersebut dapat ditarik suatu kesimpulan bahwa rata-rata $62.39 \%$ kecenderungan kecerdasan budaya mahasiswa terdapat pada dimensi CQ-Metakognitive, 66.18\% terdapat pada dimensi CQ-Kognitive, $57.07 \%$ pada dimensi CQ-Motivasi sebesar 67.23\% dan 59.08\% pada dimensi CQ behaviour. Ini menunjukan bahwa peluang untuk dikembangkannya kecerdasan budaya tersebut pada diri mahasiswa masih sangat besar. Kenyataan ini terlihat dari porsentase pada masing-masing dimensi termasuk ke dalam kategori yang baik.

Dengan demikian peluang mengembangkan kecerdasan budaya mahasiswa sangat besar yaitu melalui pengembangan pembelajaran yang dapat menunjang pencapaian secara maksimal terutama untuk mengembangkan masing-masing dimendi kecerdasan budaya sebagaimana tersebut di atas.

\section{Kesimpulan.}

Berdasarkan hasil analisis data tersebut di atas dapat ditarik kesimpulan bahwa tingkat kecerdasan budaya mahasiswa berdasarkan data angket yang diperoleh secara umum menunjukan sebagian besar mahasiswa berada dalam kondisi kecerdasan budaya dengan kategori baik yang ditunjukan dengan capaian rata-rata skor porsentase yang cukup besar yaitu 62.39\%. Secara spesifik, dimensi kecerdasan budaya hamper merata pada setiap dimensi. Ini menunjukkan bahwa mahasiswa memiliki kesadaran, pemahaman, motivasi dan harapan untuk membangun kecerdasan budaya mereka yang baik dalam berinteraksi dengan orang lain dari budaya yang berbeda dengan mereka. Hanyak saja dari data yang diperoleh perlu dikaji secara lebih mendalam melalui data wawancara untuk mengetahui keakuratan informasi yang diperoleh dengan menggunakan metode yang berbeda, sehingga data tentang kecerdasan budaya mahasiswa dapat dipahami dengan lebih baik. 


\section{Implikasi.}

Mengembangkan kecerdasan budaya pada masyarakat yang multi budaya berimplikasi pada terbangunnya kecerdasan individu secara utuh dan menjadi salah satu variabel yang harus dikaji secara lebih mendalam melalui penelitian. Terkait dengan penelitian ini maka diharapkan akan tergambarnya kemampuan individu mahasiswa calon guru pendidikan ekonomi FKIP Universita Samawa Sumbawa Besar sehingga berimplkasi pada langkah-langkah yang akan diambil sebagai upaya untuk meningkatkan kecerdasan budayanya. Dengan demikian maka upaya meningkatkan kecerdasan budaya pada mahasiswa calon guru berimplikasi pada (1) penetapan model pembelajaran yang akan dipilih dan digunakan yaitu hendaknya model pembelajaran yang digunakan sesuai dengan tujuan pembelajaran sehingga perolehan kecerdasan tersebut dapat dicapai secara lebih efisien dan efektif, (2) penetapan materi perkuliahan yaitu hendaknya materi perkuliahan disesuaikan dengan kebutuhan mahasiswa dan situasi keragaman mahasiswa, (3) implikasi terhadap alat evaluasi yaitu hendaknya alat evaluasi dirancang sesuai dengan indikator kecerdasan budaya, (4) implikasi terhadap rancangan penelitian yaitu hendaknya penelitian dirancang dengan model yang baru terutama pada rancangan pengembangannya dan hendaknya disesuaikan dengan masalah yang hendak dipecahkan, (5) implikasi terhadap hasil penelitian yaitu hendakanya hasil penelitian dapat mengispirasi peneliti lain untuk mengkaji lebih dalam terkait dengan variabel kecerdasan budaya yang belum diungkapkan melalui penelitian ini.

\section{Referensi}

Bambang Prihadi, 2013. Emantic Differential Sebagai Alat Ukur Respons Estetik Siswa diakses di http://staff.uny.ac.id/sites/default/files/131662618/artikel\%20bambangpri.pdf, tanggal 05-01-2015.

David Livermore, 2009. Cultural Intelligence: Improving Your CQ to Engage Our Multicultural World. Baker Academic, a division of Baker Publishing Group, Used by permission.

2010. Leading with cultural intelligence: the new secret to success. Broadway, New York: American Management Association.

2011. The cultural intelligence difference: master the one skill you can't do without in today's global economy. New York: American Management Association.

Ebrahim Khodadady and Shima Ghahari (2011:2) Validation of the Persian Cultural Intelligence Scale and Exploring Its Relationship with Gender, Education, 
TravellingAbroad and Place of Living. Global Journal of HUMAN SOCIAL SCIENCE Volume 11 Issue 7 Version 1.0 November 2011 Type: Double Blind Peer Reviewed International Research Journal Publisher: Global Journals Inc. (USA) Online ISSN: 2249-460x \& Print ISSN: 0975-587X

Elisabeth Plum. 2007. Cultural Intelligence:A concept for bridging and benefiting from cultural differences. www.kulturelintelligens.dk/Cultural_Intelligence. Diakses pada tanggal 22 Oktober 2014.

Joo-Seng Tan, 2004. Issues and observation: Cultural intelligence and the global economy. Lia. Volume 24, Number 5 • November/December 2004

Kemendiknas. 2010. Rencana Straregis Kementrian Pendidikan Nasional 2010-2014. diakses di.http://planipolis.iiep.unesco.org/upload/Indonesia/Indonesia_Education_Strategi c plan_2010-2014.pdf. tanggal 24 Oktober 2014.

Kok-Yee Ng and P. Christopher Earley, 2006. Cultural + Intelligence. Old constructs, New Prontier. Group \& Organization Management, Vol. 31 No. 1, February 2006 4-19. DOI: 10.1177/1059601105275251 @ 2006 Sage Publications.

Linn Van Dyne, Soon Ang, dan David Livermore. 2009. Cultural Intelligence: A Pathway for Leading in a Rapidly Globalizing World. In K.M. Hannum. B. McFeeters, \& L. Booysen(Eds.), Leadership across differ ences: Cases and perspectives: San Francisco, CQ: Pfeiffer.

Lynn Imai dan Michele J. Gelfand. 2010. The culturally intelligent negotiator: The impact of cultural intelligence (CQ) on negotiation sequences and outcomes. Organizational Behavior and Human Decision Processes (2010), doi:10.1016/j.obhdp.2010.02.001.

Masri Singarimbun \& Sofian Effendi. 2006. Metode Penelitian Survai. Jakarta: Pustaka LP3ES.

Melani James dan Maulina Pia Wulandari, 2014. Cultural intelligence key to future of Australia-Indonesiarelationship. Diakses di http://theconversation.com/culturalintelligence-key-to-future-of-australia-indonesia-relationship-29080. $\quad$ tanggal 24 Oktober 2014.

S. Margono, 2010. Metode Penelitian Pendidikan, Jakarta: Rineka Cipta.

Soon Ang, Lynn Van Dyne, dan Mei Ling Tan. 2010. Cultural intelligence (CQ). Diakses di http://www.linnvandyne.com/cq.html. tanggal 24 Oktober 2014.

Soon Ang and Linn van Dyne, 2008. Handbook of cultural intelligence: theory, measurement, and applications. Armonk New York: ME Sharpe, Inc.

Sukardi. 2009. Metode Penelitian Pendidikan Kompetensi dan Prakteknya. Jakarta: Bumi Aksara. 
Syaifuddin Iskandar. 2010. Konflik Etnis Samawa dengan Etnis Bali: Tinjauan Sosial Politik dan Upaya Resolusi Konflik. Jurnal Unsa Progres. Volume 23, Nomor 4. Hal: 286-292.

Yvonne du Plessis. 2011. Cultural Intelligence as Managerial Competence. Diakses di http://repository.up.ac.za/handle/2263/18778. tanggal 22 Oktober 2014. 